\title{
Avian Community Composition in Response to High Explosive Testing Operations at Los Alamos National Laboratory in Northern New Mexico
}

\author{
David C. Keller ${ }^{1}$, Philip R. Fresquez ${ }^{1}$, Leslie A. Hansen'1, Danielle R. Kaschube² \\ ${ }^{1}$ Environmental Stewardship, Los Alamos National Laboratory, Los Alamos, NM, USA \\ ${ }^{2}$ The Institute for Bird Populations, Point Reyes Station, CA, USA \\ Email: dckeller@lanl.gov
}

Received 13 November 2015; accepted 25 December 2015; published 28 December 2015

Copyright (C) 2015 by authors and Scientific Research Publishing Inc.

This work is licensed under the Creative Commons Attribution International License (CC BY). http://creativecommons.org/licenses/by/4.0/

(c) $\underset{\mathrm{EY}}{\mathrm{B}}$ Open Access

\section{Abstract}

Breeding bird abundance, species richness, evenness, diversity, composition, productivity, and survivorship were determined near a high-explosive detonation site at Los Alamos National Laboratory, New Mexico, USA, during pre-operation (1997-1999) and operation (2000-2014) periods. The operation periods consisted of detonations $(<23 \mathrm{~kg}$ in yield and $<3$ per breeding season) in open air (2000-2002), within foam containment (2003-2006) and within steel vessel containment (2007-2014) systems; the latter two were employed to reduce noise and dispersal of high-explosives residues. A total of 2952 bird captures, representing 80 species, was recorded during 18 years of mist net operations using the Monitoring Avian Productivity and Survivorship protocol. Individuals captured were identified to species, aged, sexed, and banded during May through August of each year. There were no significant differences $(p>0.05)$ in mean avian abundance and species evenness in any of the operation periods as compared with the pre-operation period. Species richness and diversity were significantly higher $(p<0.05)$ during the vessel containment period (2007-2014) than the pre-operation period. The time period of this study coincided with a wildfire (2000), a bark beetle infestation (2002), and two periods of drought (Nov 1999-Mar 2004 and Dec 2005-Dec 2014) that affected the study area. Analysis of aerial photos determined that the average percent canopy cover of mature ponderosa pines (Pinus ponderosa) within 100 feet of mist net sites declined from 12\% to 3\% between 1991 and 2014 and the percent cover of shrubs slightly increased. The percent similarity in presence/abundance between the pre-operation avian community and avian community during the open air, foam containment, and vessel containment periods were $59 \%, 63 \%$ and $68 \%$ respectively. Two bird species associated with large trees became less common over the study period (capture rate dropped below 2.0 adults per 600 net-hours relative to the pre-operations period), and four bird species associated 
with edge and scrub habitats became more common over the study period (capture rate increased to more than 2.0 adults per 600 net-hours relative to the pre-operations period). Bird demographics (productivity and survival) were not negatively affected by the initiation of firing site operations. The increase in diversity and the change in bird species composition over time were probably related to the change in vegetation from a woodland to a more open woodland/shrub environment.

\section{Keywords}

Avian Communities, MAPS, Diversity, High Explosives, Noise, Drought, Vegetation Change, Climate, Habitat, Southwest, New Mexico

\section{Introduction}

Birds are useful as indicators of environmental change because of their abundance and diversity in virtually all terrestrial habitats, diurnal nature, discrete reproductive seasonality, intermediate longevity, and high ecological position on most food webs [1]-[3]. Declines in bird abundance, acoustic interference, and changes in community structure have been shown to occur with disturbances from noise and vehicular traffic [4]-[8] and disturbance of habitat [9]-[11]. McClure et al. [7] measured a 25\% decrease in bird abundance and almost complete avoidance by some species in noise-affected areas relative to noise-free areas. Proppe et al. [8] showed that anthropogenic noise affected some bird species independently of vegetative conditions, exacerbating the exclusion of some songbird species in otherwise suitable habitat.

Using standardized and widely-applied census methods to monitor wild bird populations provides information on population trends and demographic rates at a variety of spatial and temporal scales [12]-[14]. In North America, constant-effort mist-netting stations operated during the breeding season often follow protocols established by the Monitoring Avian Productivity and Survivorship (MAPS) program [15]. Through a cooperative network of bird-banding stations operated throughout the United States, Canada, and Mexico ( $>1200$ stations), MAPS applies standardized procedures and analysis methodologies to estimate long-term trends in avian abundance, productivity, and survivorship. Data from all the stations are compared to one another and long-term trends for many bird species are monitored on a continent-wide basis.

Los Alamos National Laboratory (LANL) is situated within a $103 \mathrm{~km}^{2}\left(40 \mathrm{mi}^{2}\right)$ area ranging in elevation from 1890 to $2377 \mathrm{~m}$ (6200 to $7800 \mathrm{ft}$ ) in north central New Mexico, approximately $100 \mathrm{~km}$ (62 mi) north-northeast of Albuquerque (Figure 1). It is within a semiarid zone comprised of four major vegetative types-one-seeded juniper (Juniperus monosperma) savannah/woodlands, piñon (Pinus edulis)-juniper woodlands, ponderosa pine (Pinus ponderosa) woodlands/forests, and mixed-conifer woodlands/forests (Figure 1). Grasslands and shrub lands occur in areas previously cleared for agricultural fields and areas impacted by stand-replacing wildfires. On average, summer temperatures range from $21^{\circ} \mathrm{C}\left(70^{\circ} \mathrm{F}\right)$ to $31^{\circ} \mathrm{C}\left(88^{\circ} \mathrm{F}\right)$ during the daytime and from $10^{\circ} \mathrm{C}$ $\left(50^{\circ} \mathrm{F}\right)$ to $15^{\circ} \mathrm{C}\left(59^{\circ} \mathrm{F}\right)$ during the nighttime. The average annual precipitation (which includes both rain and the water equivalent of frozen precipitation) is $48 \mathrm{~cm}$ (19 in). The months of July and August account for 34\% of the annual precipitation and encompass the bulk of the rainy season, which typically begins in early July and ends in early September.

The main mission at LANL is nuclear science and weapons research. Some projects involve the testing of nonnuclear firing mechanisms using high explosives at LANL firing sites. The Dual-Axis Radiographic Hydrodynamic Test (DARHT) facility was constructed between 1994 and 1999, with the first high-explosive test shots being conducted in open air from 2000 to 2002. Subsequent test shots involved high-explosive detonations within an aqueous foam blanket configuration (2003-2006) and within a closed steel containment vessel system (2007-2014) to mitigate dispersal of blast residues/fragments and reduce noise levels. In general, detonations are small in yield $(<23 \mathrm{~kg}[<50 \mathrm{lbs}]$ ), occur at a rate of 2 to 6 per year ( $<3$ during the breeding season), and emit a high-level short duration noise [16]. Although the noise levels were not measured at the test site directly, measurements of a 23-kg high-explosive detonation approximately $2 \mathrm{~km}(1.3 \mathrm{mi})$ away averaged $118 \mathrm{~dB}$ and $6.8 \mathrm{~Hz}$ [16]. It was estimated that the use of foam and vessel containment would reduce the levels of blast residues and 


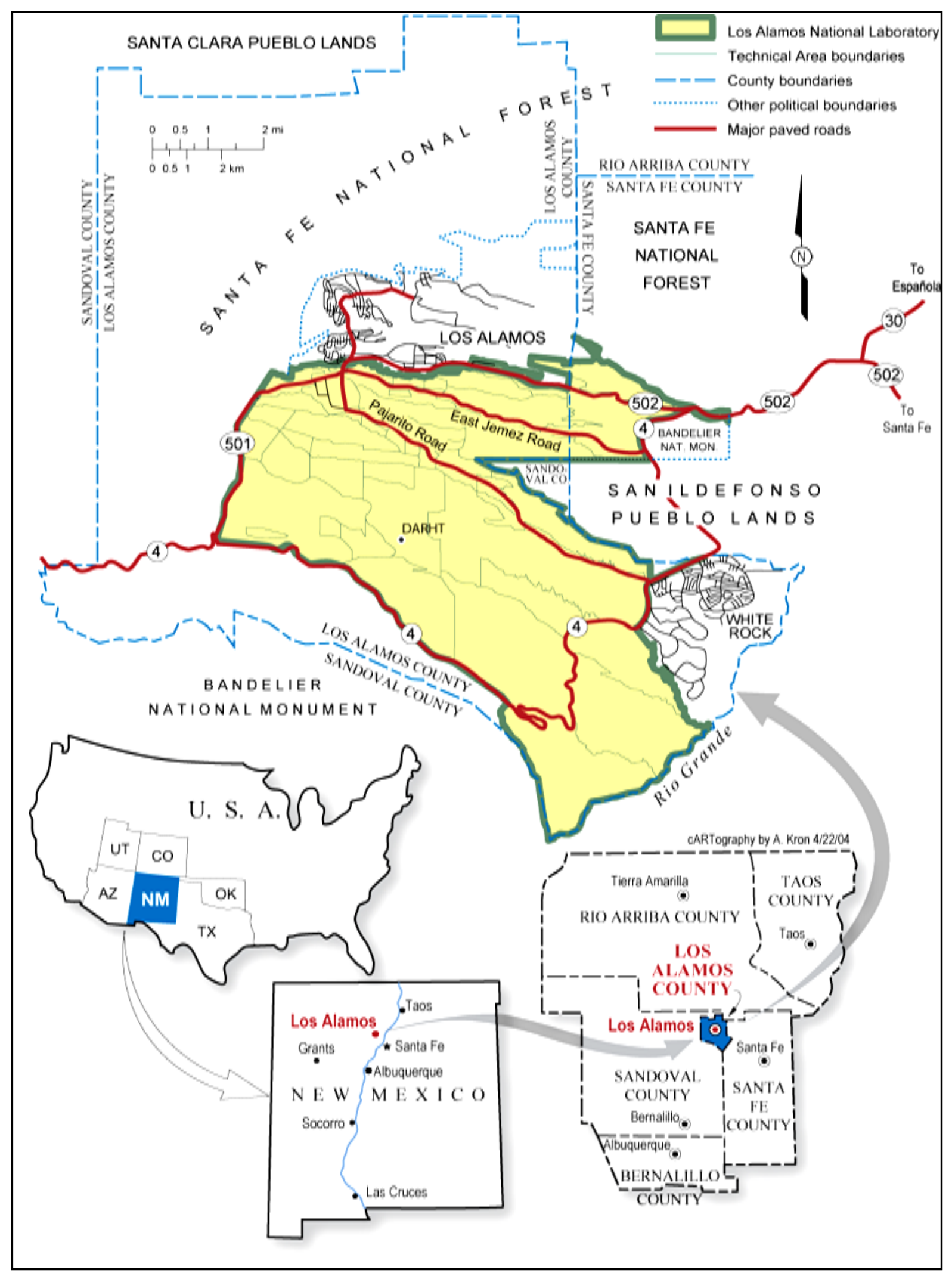

Figure 1. Location of Los Alamos National Laboratory and study site near the Dual-Axis Radiographic Hydrodynamic Test facility. 
noise by $5 \%$ to $40 \%$ and $40 \%$ to $75 \%$, respectively [16]. Actual measurements of the reduction in the dispersal of blast residues from the firing site as a result of foam and vessel containment relative to open air detonations averaged $80 \%$ and $99.9 \%$, respectively [17].

As part of the environmental surveillance program at LANL, the perimeter of the DARHT firing site was monitored for a series of ecosystem aspects prior to and during operations [18]. All chemical concentrations measured in soil, sediment, vegetation, bees, and small mammals throughout all operation periods were below ecological screening levels protective of biota [19]. The present study reports on the abundance, diversity, and composition of breeding bird populations using the MAPS protocol along a $0.70-\mathrm{km}(0.40-\mathrm{mi})$ transect on the northwest side of the DARHT facility prior to (1997-1999) and during high-explosive detonation operations employing various non-containment and containment systems (2000-2014). Sixteen years of data from this site (1997-2012) were used to calculate trends in abundance, productivity, and survivorship of breeding birds.

\section{Methods and Materials}

The DARHT firing site is located in the central part of the LANL complex (Figure 1). In 1997, 12 mist net lanes were established on the northwest side of the firing site. The net lanes were located approximately $343 \mathrm{~m}$ (1125

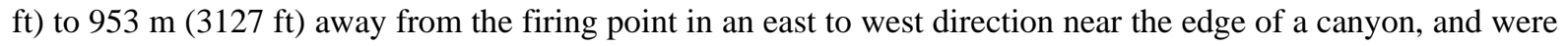
spaced approximately $46 \mathrm{~m}$ (150 ft) from one another to maximize the number of birds captured [20].

The site was classified at the start of the study as a ponderosa pine woodland [18]. We examined quantitative changes in the vegetative community surrounding the mist net locations between pre-operation and operation periods using ortho-rectified aerial photography from 1991 and 2014. Circles of $31 \mathrm{~m} \mathrm{(100ft)} \mathrm{radius} \mathrm{centered} \mathrm{on}$ six of the 12 mist net locations, picked in an alternate manner, were created in a Geographic Information System

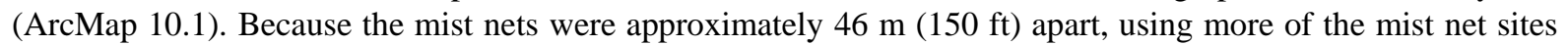
would have resulted in overlapping circles. The circles contained a point grid that represented a point approx-

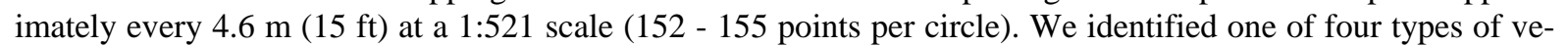
getation as the overstory cover type at each point: mature ponderosa pine; young trees (ponderosa pine) or woodland tree species (one-seeded juniper or piñon pine); shrubs [primarily oak shrub species (Quercus gambelii or undulata), but also including mountain mahogany (Cercocarpus montanus) and other shrubs]; and no woody vegetation (grasses, other herbaceous vegetation, or bare soil/rock). We calculated percent overstory canopy cover of each vegetation type on each plot in 1991 and 2014 using the point-intercept method [21].

During one day in each of 10 consecutive 10-day periods between 1 May and 8 August, mist nets (30 mm mesh size), measuring $12 \mathrm{~m}$ (39 ft) long by $3 \mathrm{~m}$ (10 ft) high, were erected at sunrise. Birds were collected for a period of 5.5 hours per netting session ( 5.5 sessions $\times 12$ nets $\times 10$ periods $=660$ net-hours per year). All birds were identified to species, banded, aged, sexed, weighed, measured, fat scored, and checked for signs of molt. The identification of species and aging and sexing criteria were based on Pyle [22]. The breeding status (confirmed breeder, likely breeder, or non-breeder) of each species captured was determined.

Metrics reported in this paper included abundance (numbers of birds per 600 net-hours per year), species richness (number of species), species diversity and evenness. Shannon's Index of species diversity [23] was used to estimate community richness as:

$$
H=-\sum_{i=1}^{S} P_{i} \log P_{i}
$$

where $P_{i}=$ proportion of species $i$ in sample, and $S=$ number of species. The corresponding test for evenness is:

$$
J=H / H_{\max }
$$

where $H_{\max }=$ maximum possible diversity (i.e., $\log S$ ).

Also, the similarity in the relative abundance of bird species common between two samples (presence/abundance) of birds between the pre-operational and operational periods were assessed using Sørensen's Quantitative Community Coefficient. The SQCC is described by Mueller-Dombois and Ellenber [24] as:

$$
S Q C C=200 M_{w} / M_{A}+M_{B},
$$

where $M_{w}$ refers to the total of the smaller quantitative values of the species common to two samples, $M_{A}$ is the total number of individual counts in Sample A, and $M_{B}$ is the total number of individual counts in Sample B. 
The levels of overall abundance, species richness, evenness, and diversity between pre-operational and operational periods were analyzed using a Mann-Whitney nonparametric (U) test at the 0.05 probability level.

Other metrics that use the long-term data set at this study site to determine the trends in abundance, productivity, and survivorship of breeding birds were analyzed for the years 1997-2012 and included the following:

Trends in Adult Population Size and Post-Fledging Productivity (Reproductive Index)-The number of first captures in a given year of adult and young birds per 600 net-hours of effort was calculated for each species. Following the procedures of Peach et al. [25], the number of adult birds of a given species captured was estimated as an index of adult population size. Also, a yearly reproductive index (RI) was calculated as the number of young for that species captured per 600 net-hours divided by the number of adults captures per 600 net-hours. Years for which the reproductive index was undefined for a species (i.e., no adults of that species were captured in that year) were not included in the trend analyses.

Trends in adult capture rates and RI of 10 target species were estimated with linear regression. A target species was defined as a bird species for which an average of at least 2.0 adult birds per year were captured over the 16 years of sampling (1997-2012 = 32 year-unique captures) and for which we recorded at least two betweenyear recaptures. The 10 target bird species were Western Wood-Pewee (Contopus sordidulus), Ash-throated Flycatcher (Myiarchus cinerascens), White-breasted Nuthatch (Sitta carolinensis), Rock Wren (Salpinctes obsoletus), Western Bluebird (Sialia mexicana), Virginia's Warbler (Oreothlypis virginiae), Western Tanager (Piranga ludoviciana), Spotted Towhee (Pipilo maculatus), Chipping Sparrow (Spizella passerine), and House Finch (Haemorhous mexicanus). The significance of the correlation ( $P$-value) for each species was calculated. Because of the consistency of sampling effort in all other years, it was reasonable to use the change in annual numbers of birds per 600 net-hours to determine trends in adult population size.

Apparent Survival Rates-Using the program TMSURVIV [26] [27], the calculated maximum-likelihood estimates and SEs for adult apparent survival rates, adult recapture probability, and the proportion of residents among newly-captured adults using a time-constant, between- and within-year transient model was estimated [27]-[29] for six species with sufficient data (Ash-throated Flycatcher, White-breasted Nuthatch, Virginia's Warbler, Western Tanager, Spotted Towhee, and Chipping Sparrow). The apparent survival rate is the probability of a bird banded at a given station in a given year surviving to the next year and remaining at the same station. The use of the transient model accounts for the existence of transient adults (dispersing and floater individuals only captured once) in the sample of newly-captured birds, and provides survival estimates that are unbiased with respect to these transient individuals [28].

\section{Results and Discussion}

The study site was initially categorized in 1997 as a ponderosa pine woodland [18]. However, during the course of this study, the area was subjected to a major wildfire (the Cerro Grande Fire) in early 2000 [30], a severe bark beetle infestation in 2002 that attacked mature pine trees [31], and two periods of drought (November 1999March 2004 and December 2005-December 2014) [32] [33]. As a result of these factors, the amount of ponderosa pine tree canopy cover on the study site decreased and shrubs increased. Specifically, the average overstory canopy cover of mature ponderosa pines within $31 \mathrm{~m}$ of the mist nets decreased from $12 \%$ to $3 \%$ (a $75 \%$ reduction), with two plots containing no mature ponderosa pine canopy cover by 2014. The average area without any woody vegetation increased from $66 \%$ to $75 \%$. There was also a slight decrease in the average cover of young/ woodland trees (from $7 \%$ to $4 \%$ ), and a slight increase in the average cover of shrub species such as Gambel's oak and mountain mahogany (from 15\% to 18\%). These changes are consistent with regionally observed pine tree mortality related to drought stress and bark beetle outbreaks [34]-[36].

A total of 2952 bird captures representing 80 species were recorded at LANL between 1997 and 2014 (Table 1). The 10 most frequently captured bird species regardless of time period were, in descending order: Virginia's Warbler, Chipping Sparrow, Western Bluebird, Western Tanager, Broad-tailed Hummingbird (Selasphorus platycercus), Rock Wren, Spotted Towhee, Bushtit (Psaltriparus minimus), Blue-gray Gnatcatcher (Polioptila caerulea), and Mountain Chickadee (Poecile gambeli). Several species collected over the years, including the Brewer's Sparrow (Spizella breweri), Grace's Warbler (Setophaga graciae), and Juniper Titmouse (Baeolophus ridgwayi) are listed as birds of concern for the Southwestern United States [37] and the Brewer's Sparrow, Grace's Warbler, Olive-sided Flycatcher (Contopus cooperi), Rufous Hummingbird (Selasphorus rufus), and Virginia's Warbler are listed as birds most at risk in North America [38]. 
Table 1. Total, \% relative abundance and rank ( $>2 \%$ abundance) of birds during pre-operational and operational periods near a firing site at Los Alamos National Laboratory.

\begin{tabular}{|c|c|c|c|c|c|c|c|c|c|c|c|c|}
\hline \multirow{4}{*}{ Species } & \multicolumn{3}{|c|}{ Pre-Operations } & \multicolumn{9}{|c|}{ Operations } \\
\hline & & & & \multicolumn{3}{|c|}{ Open Air } & \multicolumn{3}{|c|}{ Foam Containment } & \multicolumn{3}{|c|}{ Vessel Containment } \\
\hline & \multicolumn{3}{|c|}{$(1997-1999)$} & \multicolumn{3}{|c|}{$(2000-2002)$} & \multicolumn{3}{|c|}{$(2003-2006)$} & \multicolumn{3}{|c|}{$(2007-2014)$} \\
\hline & Total & $\%$ & Rank & Total & $\%$ & Rank & Total & $\%$ & Rank & Total & $\%$ & Rank \\
\hline Acorn Woodpecker & 1 & 0.23 & & 0 & 0.00 & & 0 & 0.00 & & 17 & 1.3 & \\
\hline American Kestrel & 1 & 0.23 & & 0 & 0.00 & & 0 & 0.00 & & 0 & 0.00 & \\
\hline American Robin & 4 & 0.92 & & 0 & 0.00 & & 1 & 0.11 & & 9 & 0.68 & \\
\hline Ash-throated Flycatcher & 12 & 2.8 & 9 & 1 & 0.36 & & 16 & 1.7 & & 27 & 2.0 & 13 \\
\hline Audubon's Warbler & 6 & 1.4 & & 6 & 2.1 & 12 & 34 & 3.7 & 7 & 25 & 1.9 & \\
\hline Bewick’s Wren & 0 & 0.00 & & 0 & 0.00 & & 4 & 0.44 & & 4 & 0.30 & \\
\hline Black-chinned Hummingbird & 1 & 0.23 & & 0 & 0.0 & & 1 & 0.11 & & 35 & 2.7 & 8 \\
\hline Black-throated Gray Warbler & 0 & 0.00 & & 0 & 0.00 & & 1 & 0.11 & & 2 & 0.15 & \\
\hline Blue-gray Gnatcatcher & 0 & 0.0 & & 0 & 0.0 & & 11 & 1.2 & & 71 & 5.4 & 5 \\
\hline Brewer’s Sparrow & 0 & 0.00 & & 0 & 0.00 & & 0 & 0.00 & & 8 & 0.61 & \\
\hline Broad-tailed Hummingbird & 26 & 6.0 & 4 & 9 & 3.2 & 8 & 42 & 4.6 & 6 & 70 & 5.3 & 6 \\
\hline Brown Creeper & 0 & 0.00 & & 0 & 0.00 & & 1 & 0.11 & & 2 & 0.15 & \\
\hline Brown-headed Cowbird & 0 & 0.00 & & 0 & 0.00 & & 0 & 0.00 & & 6 & 0.45 & \\
\hline Bullock’s Oriole & 0 & 0.00 & & 0 & 0.00 & & 1 & 0.11 & & 1 & 0.08 & \\
\hline Bushtit & 10 & 2.3 & 12 & 19 & 6.8 & 5 & 23 & 2.5 & 11 & 32 & 2.4 & 9 \\
\hline Calliope Hummingbird & 1 & 0.23 & & 1 & 0.36 & & 1 & 0.11 & & 8 & 0.61 & \\
\hline Canyon Towhee & 1 & 0.23 & & 1 & 0.36 & & 1 & 0.11 & & 0 & 0.00 & \\
\hline Cassin’s Kingbird & 0 & 0.00 & & 0 & 0.00 & & 1 & 0.11 & & 0 & 0.00 & \\
\hline Chipping Sparrow & 77 & 18 & 2 & 36 & 13 & 1 & 117 & 13 & 1 & 154 & 12 & 2 \\
\hline Clark's Nutcracker & 0 & 0.00 & & 2 & 0.71 & & 0 & 0.00 & & 0 & 0.00 & \\
\hline Common Nighthawk & 0 & 0.00 & & 0 & 0.00 & & 1 & 0.11 & & 0 & 0.00 & \\
\hline Common Poorwill & 1 & 0.23 & & 0 & 0.00 & & 1 & 0.11 & & 0 & 0.00 & \\
\hline Cordilleran Flycatcher & 0 & 0.00 & & 0 & 0.00 & & 4 & 0.44 & & 7 & 0.53 & \\
\hline Downy Woodpecker & 0 & 0.00 & & 2 & 0.71 & & 0 & 0.00 & & 1 & 0.08 & \\
\hline Dusky Flycatcher & 2 & 0.46 & & 0 & 0.00 & & 8 & 0.87 & & 13 & 1.0 & \\
\hline Grace’s Warbler & 0 & 0.00 & & 0 & 0.00 & & 0 & 0.00 & & 3 & 0.23 & \\
\hline Gray Flycatcher & 15 & 3.5 & 8 & 20 & 7.1 & 4 & 12 & 1.3 & & 11 & 0.8 & \\
\hline Gray-headed Junco & 0 & 0.00 & & 2 & 0.71 & & 15 & 1.6 & & 15 & 1.1 & \\
\hline Green-tailed Towhee & 2 & 0.46 & & 1 & 0.36 & & 6 & 0.65 & & 9 & 0.7 & \\
\hline Hairy Woodpecker & 3 & 0.7 & & 17 & 6.1 & 6 & 15 & 1.6 & & 12 & 0.9 & \\
\hline Hepatic Tanager & 0 & 0.00 & & 0 & 0.00 & & 0 & 0.00 & & 9 & 0.68 & \\
\hline Hermit Thrush & 4 & 0.92 & & 5 & 1.79 & & 7 & 0.76 & & 8 & 0.6 & \\
\hline House Finch & 2 & 0.5 & & 4 & 1.4 & & 26 & 2.8 & 9 & 16 & 1.2 & \\
\hline House Wren & 0 & 0.00 & & 1 & 0.36 & & 2 & 0.22 & & 13 & 0.98 & \\
\hline Juniper Titmouse & 1 & 0.23 & & 5 & 1.8 & & 9 & 0.98 & & 20 & 1.5 & \\
\hline Lark Sparrow & 2 & 0.46 & & 0 & 0.00 & & 1 & 0.11 & & 2 & 0.15 & \\
\hline
\end{tabular}




\section{Continued}

\begin{tabular}{|c|c|c|c|c|c|c|c|c|c|c|c|c|}
\hline Lazuli Bunting & 0 & 0.00 & & 0 & 0.00 & & 0 & 0.00 & & 2 & 0.15 & \\
\hline Lesser Goldfinch & 2 & 0.46 & & 3 & 1.07 & & 11 & 1.20 & & 5 & 0.4 & \\
\hline MacGillivray’s Warbler & 0 & 0.00 & & 2 & 0.71 & & 2 & 0.22 & & 30 & 2.3 & 11 \\
\hline Mountain Bluebird & 3 & 0.69 & & 0 & 0.00 & & 14 & 1.52 & & 3 & 0.2 & \\
\hline Mountain Chickadee & 24 & 5.5 & 5 & 15 & 5.4 & 7 & 12 & 1.3 & & 28 & 2.1 & 12 \\
\hline Mourning Dove & 0 & 0.00 & & 1 & 0.36 & & 0 & 0.00 & & 2 & 0.15 & \\
\hline Myrtle Warbler & 0 & 0.00 & & 0 & 0.00 & & 0 & 0.00 & & 2 & 0.15 & \\
\hline Northern Mockingbird & 0 & 0.00 & & 0 & 0.00 & & 4 & 0.44 & & 3 & 0.23 & \\
\hline Olive-sided Flycatcher & 0 & 0.00 & & 0 & 0.00 & & 1 & 0.11 & & 1 & 0.08 & \\
\hline Orange-crowned Warbler & 0 & 0.00 & & 0 & 0.00 & & 2 & 0.22 & & 4 & 0.30 & \\
\hline Oregon Junco & 0 & 0.00 & & 8 & 2.86 & 10 & 0 & 0.00 & & 1 & 0.08 & \\
\hline Pine Siskin & 1 & 0.23 & & 5 & 1.79 & & 2 & 0.22 & & 2 & 0.15 & \\
\hline Plumbeous Vireo & 4 & 0.92 & & 0 & 0.00 & & 4 & 0.44 & & 13 & 1.0 & \\
\hline Pygmy Nuthatch & 16 & 3.7 & 7 & 9 & 3.2 & 9 & 6 & 0.65 & & 7 & 0.5 & \\
\hline Red-breasted Nuthatch & 0 & 0.00 & & 0 & 0.00 & & 2 & 0.22 & & 0 & 0.00 & \\
\hline Red-shafted Flicker & 7 & 1.6 & & 7 & 2.50 & 11 & 6 & 0.65 & & 3 & 0.2 & \\
\hline Rock Wren & 0 & 0.0 & & 0 & 0.0 & & 60 & 6.5 & 5 & 74 & 5.6 & 4 \\
\hline Ruby-crowned Kinglet & 1 & 0.23 & & 0 & 0.00 & & 2 & 0.22 & & 1 & 0.08 & \\
\hline Rufous Hummingbird & 5 & 1.2 & & 3 & 1.1 & & 25 & 2.7 & 10 & 16 & 1.2 & \\
\hline Savannah Sparrow & 3 & 0.69 & & 0 & 0.00 & & 0 & 0.00 & & 0 & 0.00 & \\
\hline Say's Phoebe & 0 & 0.00 & & 1 & 0.36 & & 3 & 0.33 & & 14 & 1.1 & \\
\hline Scarlet Tanager & 0 & 0.00 & & 0 & 0.00 & & 0 & 0.00 & & 1 & 0.08 & \\
\hline Song Sparrow & 0 & 0.00 & & 1 & 0.36 & & 0 & 0.00 & & 0 & 0.00 & \\
\hline Spotted Towhee & 19 & 4.4 & 6 & 2 & 0.71 & & 30 & 3.3 & 8 & 61 & 4.6 & 7 \\
\hline Steller’s Jay & 4 & 0.92 & & 1 & 0.36 & & 0 & 0.00 & & 2 & 0.15 & \\
\hline Townsend's Solitaire & 5 & 1.2 & & 2 & 0.71 & & 5 & 0.54 & & 13 & 1.0 & \\
\hline Townsend's Warbler & 0 & 0.00 & & 0 & 0.00 & & 1 & 0.11 & & 0 & 0.00 & \\
\hline Vesper Sparrow & 2 & 0.46 & & 0 & 0.00 & & 1 & 0.11 & & 2 & 0.15 & \\
\hline Violet-green Swallow & 2 & 0.46 & & 0 & 0.00 & & 5 & 0.54 & & 8 & 0.61 & \\
\hline Virginia's Warbler & 92 & 21 & 1 & 34 & 12 & 2 & 98 & 11 & 3 & 161 & 12 & 1 \\
\hline Warbling Vireo & 2 & 0.46 & & 0 & 0.00 & & 0 & 0.00 & & 17 & 1.3 & \\
\hline Western Bluebird & 35 & 8.1 & 3 & 29 & 10 & 3 & 79 & 8.6 & 4 & 98 & 7.4 & 3 \\
\hline Western Kingbird & 0 & 0.00 & & 0 & 0.00 & & 0 & 0.00 & & 1 & 0.08 & \\
\hline Western Scrub-Jay & 3 & 0.69 & & 2 & 0.71 & & 3 & 0.33 & & 20 & 1.5 & \\
\hline Western Tanager & 11 & 2.5 & 11 & 4 & 1.4 & & 113 & 12 & 2 & 31 & 2.3 & 10 \\
\hline Western Wood-Pewee & 4 & 0.92 & & 1 & 0.4 & & 21 & 2.3 & 12 & 25 & 1.9 & \\
\hline White-breasted Nuthatch & 3 & 0.69 & & 5 & 1.8 & & 21 & 2.3 & 13 & 26 & 2.0 & 14 \\
\hline White-crowned Sparrow & 0 & 0.00 & & 3 & 1.07 & & 0 & 0.00 & & 1 & 0.08 & \\
\hline White-winged Dove & 0 & 0.00 & & 0 & 0.00 & & 0 & 0.00 & & 1 & 0.08 & \\
\hline Williamson’s Sapsucker & 0 & 0.00 & & 5 & 1.79 & & 1 & 0.11 & & 0 & 0.00 & \\
\hline Wilson's Warbler & 1 & 0.23 & & 2 & 0.71 & & 7 & 0.76 & & 13 & 1.0 & \\
\hline Yellow Warbler & 1 & 0.23 & & 0 & 0.00 & & 1 & 0.11 & & 1 & 0.08 & \\
\hline Grand Total & 433 & 100 & & 280 & 100 & & 919 & 100 & & 1320 & 100 & \\
\hline
\end{tabular}


No avian community metric (abundance, species richness, diversity, or evenness) was significantly different $(p>0.05)$ in the open air or foam containment detonation periods as compared with the pre-operation period (Table 2). Species richness and diversity increased significantly $(p<0.05)$ in the vessel containment period of operations relative to the pre-operation period.

Although the community metrics were not significantly affected by firing site operations, the species composition of birds did change over time. Using Sørensen's Quantitative Community Coefficient, the percent similarity between the pre-operation avian community and the open air, foam containment, and vessel containment periods were 59\%, 63\% and 68\% respectively. Of the species that were common only in the pre-operations period, two of the three (Pygmy Nuthatch [Sitta pygmaea] and Black-headed Grosbeak [Pheucticus melanocephalus]) are highly associated with large trees such as mature ponderosa pine [39] (Table 3). Of the bird species common only in the vessel containment period, four of the five (Blue-gray Gnatcatcher [Polioptila caerulea], Blackchinned Hummingbird [Archilochus alexandri], MacGillivray's Warbler [Geothlypis tolmiei], and Whitebreasted Nuthatch) are associated with habitat edges and scrublands [39]. Studies have shown that a change in the vegetative physiognomy following a forest stand-replacement event in the Rocky Mountain region may change the composition of bird species considerably [40]-[42].

An analysis of long-term data from the years 1997 through 2012 (16 years) showed that, overall, bird demographics were not negatively affected by the initiation of firing site operations and were not in decline compared to populations elsewhere in North America [15] [43]. The mean number of adults and young captured was 84 and 23 per 600 net-hours per year, respectively, for a mean reproduction index of 0.28 .

None of the 10 target bird species exhibited significant $(\mathrm{p}>0.05)$ decreasing trends in abundance or productivity over the 16-year time period. In contrast, Spotted Towhee and Rock Wren showed significantly $(\mathrm{p}<0.05)$ increasing abundance over time (Figure 2) and the Chipping Sparrow showed significantly $(\mathrm{p}<0.05)$ increasing productivity over time (Figure 3). The long-term trend for all species pooled for abundance and productivity were increasing (slope $=2.9$ and 0.015 , respectively) but not statistically significant $(\mathrm{p}=0.30$ and $\mathrm{p}=0.15$, respectively).

Table 2. Mean (SD) bird metrics near a high explosive site during pre-operational and operational periods 1997-2014) at Los Alamos National Laboratory.

\begin{tabular}{|c|c|c|c|c|}
\hline Activity (year) & Abundance & Species Richness & Diversity & Evenness \\
\hline Pre-Operation (1997-1999) & 144 (18) & $28(1.5)$ & $2.7(0.15)$ & $0.81(0.05)$ \\
\hline \multicolumn{5}{|l|}{ Operations } \\
\hline Open Space (2000-2002) & $93(41)$ & $23(5.5)$ & $2.7(0.17)$ & $0.86(0.040)$ \\
\hline Foam Containment (2003-2006) & $230(152)$ & $35(8.7)$ & $2.9(0.13)$ & $0.83(0.053)$ \\
\hline Vessel Containment (2007-2014) & $165(54)$ & $37(5.2)^{*}$ & $3.2(0.093)^{*}$ & $0.83(0.079)$ \\
\hline
\end{tabular}

*Denotes significantly different from the pre-operation mean using a Mann-Whitney Test at the 0.05 probability level.

Table 3. Species composition of common bird species ( $>2$ adults captured per 600 net-hours) captured in mist nest near the DARHT facility during the pre-operational and vessel containment periods.

\begin{tabular}{ccc}
\hline Birds common to both periods & Birds common only in pre-operations & Birds common only in vessel containment period \\
\hline Virginia Warbler & Pygmy Nuthatch & Rock Wren \\
Chipping Sparrow & Black-headed Grosbeak & Black-chinned Hummingbird \\
Western Bluebird & & MacGillivray’s Warbler \\
Broad-tailed Hummingbird & White-breasted Nuthatch \\
Mountain Chickadee & \\
Spotted Towhee & \\
Ash-throated Flycatcher & \\
Bushtit &
\end{tabular}




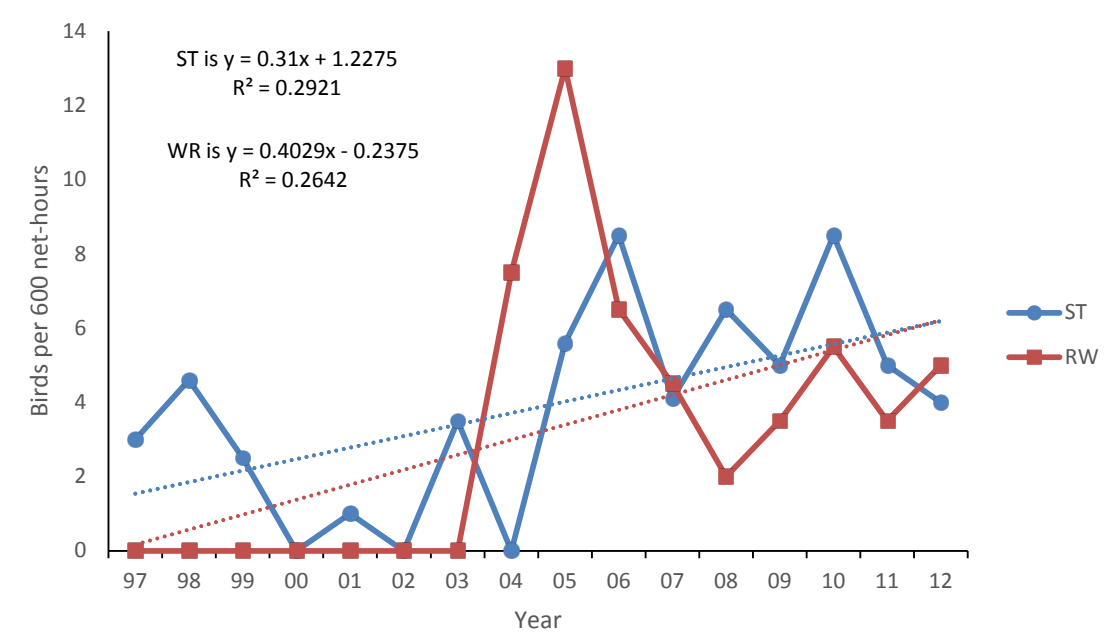

Figure 2. Trend in abundance for Spotted Towhee (ST) and Rock Wren (RW) near a firing site at the Los Alamos National Laboratory over 16 years (1997-2012).



Figure 3. Trend in productivity for Chipping Sparrow near a firing site at the Los Alamos National Laboratory over 16 years (1997-2012).

The maximum-likelihood estimates of apparent annual adult survival probability, recapture probability, and proportion of residents among newly-captured adults of six target bird species breeding near the DARHT facility at LANL from the time-constant transient model are presented in Table 4. Annual adult survival-rate estimates ranged from a low of 0.27 for the Western Tanager to a high of 0.71 for the White-breasted Nuthatch, with a mean of 0.50 for the six species. The coefficient of variation for four of the six species at the LANL study site were low (four of the six species $<30 \%$ of which two species $<20 \%$ ) indicating quite precise estimates. Furthermore, survival of adult birds at the study site appears to be slightly higher for the four well estimated species than that at other MAPS stations in the Southwest MAPS Region [15] [43].

\section{Conclusion}

Bird populations living near an active firing site at LANL were not significantly impacted by either open air or contained detonation activities at the current yield(s), frequency, distance from the firing site, and/or apparent noise level(s). Diversity increased and the composition of birds changed with the efficiency of the containment system(s) over time; however, these changes were probably more related to the conversion in vegetation from a ponderosa pine woodland environment to a more open woodland/shrub environment than to nearby firing site operations. The increase in bird diversity may have been caused by the addition of bird species that are well adapted to edge and shrub habitats after the loss of many mature ponderosa pines in the study area. 
Table 4. Estimates of apparent adult annual survival and recapture probabilities and proportion of residents among newlycaptured adults using a time-constant model for six species breeding at the Los Alamos National Laboratory MAPS Station obtained from 1997-2012 (16 years) of mark-recapture data.

\begin{tabular}{|c|c|c|c|c|c|c|c|c|c|c|}
\hline \multirow{3}{*}{$\begin{array}{l}\text { Species } \\
\text { roatedFlycatcher }\end{array}$} & \multicolumn{3}{|c|}{ Number } & \multirow{2}{*}{\multicolumn{2}{|c|}{$\begin{array}{c}\text { Survival } \\
\text { Probability }( \pm S E)^{4 \mathrm{~d}}\end{array}$}} & \multirow{3}{*}{$\begin{array}{c}\text { Survival } \\
\text { C.V. } \\
24\end{array}$} & \multirow{2}{*}{\multicolumn{2}{|c|}{$\begin{array}{c}\text { Recapture } \\
\text { Probability }( \pm \mathrm{SE})^{\mathrm{f}}\end{array}$}} & \multirow{2}{*}{\multicolumn{2}{|c|}{$\begin{array}{c}\text { Proportion of } \\
\text { Residents }( \pm S E)^{\varepsilon}\end{array}$}} \\
\hline & \multirow{2}{*}{$\begin{array}{c}\text { Ind. }^{\text {a }} \\
36\end{array}$} & \multirow{2}{*}{$\begin{array}{c}\text { Caps. }^{\text {b }} \\
45\end{array}$} & \multirow{2}{*}{$\begin{array}{c}\text { Ret. }^{\mathrm{c}} \\
7\end{array}$} & & & & & & & \\
\hline & & & & 0.63 & $(0.15)$ & & 0.37 & $(0.19)$ & 0.33 & $(0.21)$ \\
\hline White-breasted Nuthatch ${ }^{\mathrm{h}}$ & 28 & 37 & 4 & 0.71 & $(0.17)$ & 24 & 0.21 & $(0.15)$ & 0.27 & $(0.24)$ \\
\hline Virginia's Warbler & 177 & 289 & 43 & 0.54 & $(0.059)$ & 11 & 0.40 & $(0.080)$ & 0.49 & $(0.13)$ \\
\hline Western Tanager ${ }^{\mathrm{h}, \mathrm{i}}$ & 146 & 149 & 3 & 0.27 & $(0.23)$ & 84 & 0.055 & $(0.22)$ & 1.0 & (4.1) \\
\hline Spotted Towhee ${ }^{i}$ & 60 & 82 & 8 & 0.33 & $(0.14)$ & 44 & 0.31 & $(0.22)$ & 1.0 & $(0.74)$ \\
\hline Chipping Sparrow & 216 & 241 & 13 & 0.55 & $(0.11)$ & 20 & 0.089 & $(0.065)$ & 0.59 & $(0.43)$ \\
\hline
\end{tabular}

${ }^{\mathrm{a}}$ Number of adult individuals captured at stations where the species was a regular or usual breeder (i.e., number of capture histories); ${ }^{\mathrm{b}}$ Total number of captures of adult birds of the species at stations where the species was a regular or usual breeder; ${ }^{\mathrm{c}}$ Total number of returns. A return is the first recapture in a given year of a bird originally banded at the same station in a previous year; ${ }^{\mathrm{d}}$ Survival probability $(\varphi)$ presented as the maximum likelihood estimate

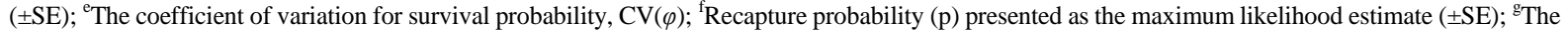
proportion of residents among newly-captured adults $(\tau)$ presented as the maximum likelihood estimate $\left( \pm\right.$ SE); ${ }^{\text {h }}$ The estimate for recapture probability (and possibly survival probability as well) may be biased low because the estimate for $\tau$ was 1.0 ; ${ }^{i}$ The estimate for survival probability should be viewed with caution because it is based on fewer than five between-year recaptures or the estimate is very imprecise $(\operatorname{SE}(\varphi) \geq 0.200$ or $\operatorname{CV}(\varphi) \geq 50.0 \%)$

\section{Acknowledgements}

We thank the following people for management oversight and field help and during this project: Stephanie Archuleta, C. Hathcock, J. Fair, M. Jankowski, H. Mahowald, B. Norris, B. Panowski, R. Robinson, L. Marsh, M. Shendo, G. Vigil, and dozens of other interns over the 18 years. This project was operated under an approved Institutional Animal Care and Use Committee protocol and was funded through Los Alamos National Security, LLC, operator of the Los Alamos National Laboratory under Contract No. DE-AC52-06NA25396 for the National Nuclear Security Administration of the US Department of Energy.

\section{References}

[1] Morrison, M.J. (1986) Bird Populations as Indicators of Environmental Change. Current Ornitholog, 3, 429-451. http://dx.doi.org/10.1007/978-1-4615-6784-4_10

[2] Canterbury, G.E. and Blockstein, D.E. (1997) Local Changes in a Breeding Bird Community Following Forest Disturbance. Journal of Field Ornithology, 68, 537-546.

[3] Hutto, R.L. (1998) Using Landbirds as an Indicator Species Group. In: Marzluff, J.M. and Sallabanks, R. Eds., Avian Conservation: Research and Management, Island Press, Washington DC, 75-92.

[4] Reijnen, R., Foppen, R., Terbraaak, C. and Thissen, J. (1995) The Effects of Car Traffic on Breeding Bird Populations in Woodland 3. Reduction of Density in Relation to the Proximity of Main Roads. Journal of Applied Ecology, 32, 187-202. http://dx.doi.org/10.2307/2404428

[5] Parris, K.M. and Schneider, S. (2008) Impacts of Traffic Noise and Traffic Volume on Birds of Roadside Habitats. Ecology and Society, 14, 29.

[6] Francis, C.C., Ortega, C.P. and Cruz, A. (2009) Noise Pollution Changes Avian Communities and Species Interactions. Current Biology, 19, 1415-1419. http://dx.doi.org/10.1016/j.cub.2009.06.052

[7] McClure, C.J.W., Ware, H.E., Carlisle, J., Kaltenecker, G. and Barber, J.R. (2013) An Experimental Investigation into the Effects of Traffic Noise on Distributions of Birds: Avoiding the Phantom Road. Proceedings of the Royal Society B: Biological Sciences, 280. http://dx.doi.org/10.1098/rspb.2013.2290

[8] Proppe, D.S., Sturdy, C.B. and Cassady St. Clair., C. (2013) Anthropongenic Noise Decreases Urban Songbird Diversity and May Contribute to Homogenization. Global Change Biology, 19, 1075-1084. http://dx.doi.org/10.1111/gcb.12098

[9] Ambuel, B. and Temple, S.A. (1983) Area-Dependent Changes in the Bird Communities and Vegetation of Southern Wisconsin Forests. Ecology, 64, 1057-1068. http://dx.doi.org/10.2307/1937814

[10] Patten, M.A. and Rotenberry, J.T. (1998) Post-disturbance Changes in a Desert Breeding Bird Community. Journal of 
Field Ornithology, 69, 614-625.

[11] Brawn, J.D., Robinson, S.K. and Thompson III, F.R. (2001) The Role of Disturbance in the Ecology and Conservation of Birds. Annual Review of Ecology and Systematics, 32, 251-276. http://dx.doi.org/10.1146/annurev.ecolsys.32.081501.114031

[12] De Sante, D.F., Burton, K.M., Velez, P. and Froehlich, D. (2002) Maps Manual 2002, Protocol Instructions for the Establishment and Operation of Constant-Effort Bird-Banding Stations as Part of the Monitoring Avian Productivity and Survivorship (MAPS) Program. The Institute for Bird Populations, Point Reyes Bird Observatory Bolinas, CA.

[13] DeSante, D.F., Saracco, J.F., O’Grady, D.R., Burton, K.M. and Walker, B.L. (2004) Some Methodological Considerations of the Monitoring Avian Productivity and Survivorship Program. Studies in Avian Biology, 29, 28-45.

[14] Robinson, R.A., Julliard, R. and Saracco, J.F. (2009) Constant Effort: Monitoring Avian Population Change through Standardized Ringing. Ringing and Migration, 24, 199-204. http://dx.doi.org/10.1080/03078698.2009.9674392

[15] DeSante, D.F. and Kaschube, D.R. (2009) The Monitoring Avian Productivity and Survivorship (MAPS) Program 2004, 2005, and 2006 Report. Bird Populations, 9, 86-169.

[16] USDOE (1995) Final Environmental Impact Statement: Dual-Axis Radiographic Hydrodynamic Test Facility. United States Department of Energy Report USDOE/EIS-0228.

[17] Duran, B. (2008) Environmental Assessment of Foam Mitigation and Vessel Contained Shots. Los Alamos National Laboratory Report LA-UR-08-2289, Los Alamos, NM.

[18] Nyhan, J.W., Fresquez, P.R., Haarmann, T., Bennett, K., Haagenstad, T., Keller, K. and Hinojosa, H. (2001) Baseline Concentrations of Radionuclides and Trace Elements in Soils, Sediments, Vegetation, Small Mammals, Birds, and Bees around the DARHT Facility: Construction Phase (1996 through 1999). Los Alamos National Laboratory Report LA-13808-MS, Los Alamos, NM.

[19] Fresquez, P.R., McNaughton, M., Hansen, L., Hathcock, C., Gaukler, S. and Keller, D. (2015) Ecosystem Health. In: Annual Site Environmental Report 2014, Los Alamos National Laboratory Report LA-UR-15-27513, Los Alamos, NM, pp. 7-1 to 7-46.

[20] Bub, H. (1996) Bird Trapping and Bird Banding: A Handbook for Trapping Methods All over the World. Cornell University Press, Ithaca.

[21] Herrick, J.E., Van Zee, J.W., Havstad, K.M., Burkett, L.M. and Whitford, W.G. (2005) Monitoring Manual for Grassland, Shrubland and Savanna Ecosystems, Volume I: Quick Start. USDA-ARS Jornada Experimental Range, PO Box 30003, MSC 3JER, NMSU, Las Cruces, New Mexico 88003-8003. http://jornada.nmsu.edu/files/Quick_Start.pdf

[22] Pyle, P. (1997) Identification Guide to North American Passerines. Slate Creek Press, Bolinas.

[23] Zar, J.H. (1974) Biostatistical Analysis. Prentice-Hall, Englewood Cliffs.

[24] Mueller-Dombois and Ellenberg, H. (1974) Aims and Methods of Vegetation Ecology. John Wiley \& Sons, New York.

[25] Peach, W.J., Buckland, S.T. and Baillie, S.R. (1996) The Use of Constant Effort Mist-Netting to Measure BetweenYear Changes in the Abundance and Productivity of Common Passerines. Bird Study, 43, 142-156. http://dx.doi.org/10.1080/00063659609461007

[26] White, G.C. (1983) Numerical Estimation of Survival Rates from Band Recovery and Biotelemetry Data. Journal of Wildlife Management, 47,716-728. http://dx.doi.org/10.2307/3808607

[27] Hines, J.E., Kendall, W.L. and Nichols, J.D. (2003) On the Use of the Robust Design with Transient Capture-Recapture Models. The Auk, 120, 1151-1158. http://dx.doi.org/10.1642/0004-8038(2003)120[1151:OTUOTR]2.0.CO;2

[28] Pradel, R.J., Hines, J.D., Lebreton and Nichols, J.D. (1997) Estimating Survival Probabilities and Proportions of Transients' Using Capture-Recapture Data. International Biometric Society, 53, 60-72. http://dx.doi.org/10.2307/2533097

[29] Nott, M.P., DeSante, D.F., Siegel, R.B. and Pyle, P. (2002) Influences of the El Niño/Southern Oscillation and the North Atlantic Oscillation on Avian Productivity in Forests of the Pacific Northwest of North America. Global Ecology and Biogeography, 11, 333-342. http://dx.doi.org/10.1046/j.1466-822X.2002.00296.X

[30] Kraig, D., Ryti, R., Katzman, D., Buhl, T., Gallaher, B. and Fresquez, P. (2001) Radiological and Nonradiological Effects after the Cerro Grande Fire. Los Alamos National Laboratory Report LA-UR-01-6868, Los Alamos, NM.

[31] LANL (2004) Compliance Summary. In: Environmental Surveillance at Los Alamos during 2002, Los Alamos National Laboratory Report LA-14085-ENV, Los Alamos, NM, 9-38.

[32] South Central Climate Science Center (2013) Drought History for the Northern Mountains of New Mexico. Norman, Oklahoma, 31 August 2015.

http://www.southcentralclimate.org/content/documents/factsheets/Drought_History_NMCD02.pdf

[33] NOAA (2015) Historical Palmer Drought Indices. 31 August 2015. 
http://www.ncdc.noaa.gov/temp-and-precip/drought/historical-palmers/

[34] Allen, C.D. and Breshears, D.D. (1998) Drought-Induced Shift of a Forest-Woodland Ecotone: Rapid Landscape Response to Climate Variation. Proceedings of the National Academy of Sciences of the United States of America, 95, 14839-14842. http://dx.doi.org/10.1073/pnas.95.25.14839

[35] Breshears, D.D., Cobb, N.S., Rich, P.M, Price, K.P., Allen, C.D., Balice, R.G., Romme, W.H., Kastens, J.H., Floyd, M.L., Belnap, J., Anderson, J.J., Myers, O.B. and Meyer, C.W. (2005) Regional Vegetation Die-Off in Response to Global-Change-Type Drought. Proceedings of the National Academy of Sciences of the United States of America, 102, 15144-15148. http://dx.doi.org/10.1073/pnas.0505734102

[36] Goeking, S.A., Shaw, J.D., Witt, C., Thompson, M.T., Werstak Jr, C.E., Amacher, M.C., Stuever, M., Morgan, T.A., Sorenson, C.B., Hayes, S.W. and McIver, C.P. (2014) New Mexico’s Forest Resources, 2008-2012. US Department of Agriculture, Forest Service, Rocky Mountain Research Station Resource Bulletin RMRS-RB-18, Fort Collins, CO.

[37] USFWS (2008) Birds of Conservation Concern. United States Department of Interior, Fish and Wildlife Service, Division of Migratory Bird Management, Arlington, Virginia, 85 p.

[38] Wells, J.V. (2007) Birder’s Conservation Handbook: 100 North American Birds at Risk. Princeton University Press, Princeton.

[39] Cornell Lab of Ornithology (2015) All about Birds Website. October 2015. www.allaboutbirds.org

[40] Hutto, R.L. (1995) Composition of Bird Communities Following Stand-Replacement Fires in the Northern Rocky Mountain (USA) Conifer Forests. Conservation Biology, 9, 1041-1058. http://dx.doi.org/10.1046/j.1523-1739.1995.9051033.x-i1

[41] Kotliar, N.B., Heil, S.J., Hutto, R.L., Saab, V.A., Melcher, C.P. and McFadzen, M.E. (2002) Effects of Fire and Post-Fire Salvage Logging on Avian Communities in Conifer-Dominated Forest of the Western United States. Studies in Avian Biology, 25, 49-64.

[42] Smucker, K.M., Hutto, R.L. and Steele, B.M. (2005) Changes in Bird Abundance after Wildfire: Importance of Fire Severity and Time since Fire. Ecological Applications, 15, 1535-1549. http://dx.doi.org/10.1890/04-1353

[43] DeSante, D.F., Burton, K.M., Saracco, J.F. and Walker, B.L. (1995) Productivity Indices and Survival-Rate Estimates from MAPS, a Continent-Wide Programme of Constant-Effort Mist-Netting in North America. Journal of Applied Statistics, 22, 935-948. http://dx.doi.org/10.1080/02664769524720 